\title{
Effrctivenes Of The Biology Learning During The Covid-19 Pandemic Class X MIPA Mas Al Wasliyah Merbau North Labuhanbatu Regency
}

\author{
Hendrika Saputra ${ }^{1)}$, Padilah $^{2)}$, Ade Irwansyah Putra Nasution ${ }^{3)}$ \\ 1,2,3) Biology Education Universitas Islam Labuhan Batu
}

*Coresponding Author

Email : endrikspd@gmail.com

\begin{abstract}
This study aims to determine the supporting and inhibiting factors as well as the effectiveness of learning biology during the covid-19 pandemic at MAS Al Wasliyah Marbau. This research is a qualitative descriptive type with data collection techniques through interviews, questionnaires, observation and documentation. Data analysis used in the form of data collection, data reduction, and data presentation. The results of this study indicate that the inhibiting factors for learning from home in biology are internet networks, student absence from online learning, economic conditions of students, and possession of gadgets or laptops. The supporting factors are technology, learning places in accordance with the COVID-19 health protocol, adequate learning resources and learning media, online learning implementation plans designed by teachers, students' enthusiastic attitude in studying, and adequate infrastructure. In conclusion, $82 \%$ of biology learning at MAS Al Wasliyah Marbau runs effectively in accordance with government regulations through Circular Letter No. 15 of 2020.
\end{abstract}

\section{Keywords: Effectiveness of Learning and Learning Biology from Home}

\section{INTRODUCTION}

Based on Law no. 20 of 2019 concerning the National Education System, explains that education in Indonesia is a conscious effort and requires planning to create a learning atmosphere and an active learning process so that students can develop their potential to have religious spiritual strength, self-control, personality, intelligence, noble character, and skills needed by himself, society, nation and state. Education is held as a process of cultivating and empowering students so that it can take place at MAS Al Washliyah Marbau Class X MIPA. Education is held by providing examples, building the will and developing talents in the form of creativity of students in the learning process.

Learning is a process carried out by teachers to provide guidance and direction to students to have expertise in learning. In addition, in learning, there must be good interaction between students and teachers. With planned learning, a learning process that is regulated in such a way as to produce the expected values is good.3 However, as of March 2020 the world health organization (WHO) has determined Corona Virus Disease (covid-19) as a pandemic that has hit more than 200 countries in the world. As a measure to anticipate the spread of COVID-19, the Indonesian government has taken several actions, starting from activities at home. Through these policies, the government wants people to stay at home, work, study and worship at home. This condition has a direct impact on the world of education. Minister of Education and Culture (Mendikbud) Nadiem Anwar Makarim revealed that the learning from home approach was the government's first strategic step in preventing the widespread spread of Corona Virus Disease (Covid-19). The health and safety of education personnel is a government priority. Nadiem also said that the benefits of technology can be applied when doing distance learning. So that the learning process can still be carried out as expected. Teachers as teaching staff are required to innovate in learning by utilizing applications that 
have been provided by the government for the educational process. For example, the Learning House application, Our Desk, WeKiddo, to Google For Education. The government also provides video conferencing tools available for all G-Suite and Google Classroom users to take classes and continue distance learning from home (source: kemdikbud.go.id).

Based on an interview I did with a biology teacher at MAS Al Washliyah Marbau at that time had not yet entered the Covid-19 outbreak at MAS Al Wasliyah Marbau Class X MIPA Indonesia. I received information that when face-to-face learning in the classroom the teacher usually uses the group discussion or lecture method. For example, on the material of the respiratory system, the teacher uses a lecture learning model or group discussion that involves students having to present the results of group discussions in front of the class. In addition, the teacher also utilizes learning media in the form of teaching aids and Powerpoint that can assist students in receiving learning so that it is hoped that the goals of the desired learning process can be achieved. Furthermore, after changing the face-to-face learning system in class to learning from home with an online method in accordance with the Ministry of Education and Culture regulations regarding efforts to prevent the corona virus outbreak, MAS Al Washliyah Marbau followed government regulations to carry out the online learning process at home. Seeing these facts, teachers are required to prepare learning methods from home which are expected to be able to meet the students' Minimum Completeness Criteria (KKM) so that learning objectives can be achieved in accordance with expectations. To find out how MAS Al Washliyah Marbau is in the online biology learning process, I conducted an interview with one of the biology teachers at MAS Al Washliyah Marbau, he said that when learning is done online, the teaching pattern that is usually done in schools cannot be completely done online . When online learning is carried out, the teacher is only able to provide material to students either through online face-to-face or E-Learning learning, this indicates that the lack of variety of learning models used by teachers during the online learning process is due to communication and face-to-face factors. limited time online. Online learning activities carried out by the biology teacher MAS Al Wasliyah Marbau are utilizing applications in the form of Google Meet and Google Classroom as face-to-face learning applications online. Then for giving questions in the form of assignments or tests using facilities in the form of E-Learning or the Whatsapp application.

Based on these facts, the authors are interested in conducting a study that discusses the effectiveness of the biology learning process during this pandemic which is packaged in a study entitled Effectiveness of Biology Learning during the Covid-19 Pandemic at MAS Al Washliyah Marbau Class X MIPA North Labuhanbatu Regency for the 2020/2021 Academic Year.

\section{RESEARCH METHODS}

\section{Research Design}

In this study, the author uses the type of research in the form of a case study (case study). This is because the research that the author is doing involves activities that focus on the development of a case involving individuals or groups who interact with each other not only focusing on a problem that is an obstacle but because of an advantage or success in research. Therefore, the author uses a case study type of research which in this study the author wants to see whether during this covid-19 pandemic there was a problem or a success that affected the learning of biology so that the effectiveness of the application of biology learning in Indonesia could be known. 
In this study, the authors used descriptive qualitative research, which means that the research components are influential and interconnected so that researchers are required to obtain systematic and accurate data. This research also refers to the facts and symptoms that occur in the field. In this study, the data is presented in the form of a complex and systematic descriptive description report. Therefore, there is no part that escapes the attention of the author in obtaining data so that careful research is produced. The reason the author uses descriptive qualitative research is because all aspects of data collection do not go unnoticed and need systematic descriptions both in writing and orally. This is because qualitative descriptive research leads to a holistic individual background.

\section{Population and Sample}

In this study, the research subjects in question were the deputy head of the madrasa in the field of curriculum, teachers in the field of biology studies, and 155 students of MAS Al Wasliyah Marbau Class X MIPA. The sample is part of the population that is the research sample, to be clear about this sample the author quotes Sukardi (2019:54) saying, "part of the population selected for the data source is called the sample".

\section{Variables and Indicators}

The variables in this study consisted of two variables, namely the independent variable and the dependent variable.

\begin{tabular}{|c|c|}
\hline Indicator & Learning objectives \\
\hline $\begin{array}{l}\text { Describe the problem of Biology and } \\
\text { the level of organization of life. }\end{array}$ & $\begin{array}{l}\text { After completing this subtopic learning, students are } \\
\text { able to: } \\
\text { 1. Explain the meaning, nature and } \\
\text { characteristics of biology as a science. } \\
2 \text { Explain the scope of the study of biology. } \\
\text { 3. Explain the objects and problems of Biology } \\
\text { at the level of molecules, cells, tissues, organs, } \\
\text { individuals, populations, ecosystems and biomes }\end{array}$ \\
\hline $\begin{array}{l}\text { Identify the branches of biology } \\
\text { according to the objects and problems } \\
\text { studied with self-development in the } \\
\text { future }\end{array}$ & $\begin{array}{l}\text { 1. Mention the fields of biological study at each } \\
\text { level of the hierarchy of life. } \\
\text { 2. Name the branches of biology according to } \\
\text { the object and problem being studied } \\
3 \text {. Mention a biology-based profession or career. }\end{array}$ \\
\hline $\begin{array}{l}\text { Analyzing MAS Al Washliyah Marbau } \\
\text { the benefits of studying biology for } \\
\text { MASA Al Wasliyah Marbau age, } \\
\text { environment, and } \\
\text { the future of civilization. }\end{array}$ & $\begin{array}{l}\text { 1. Explain the role of biology for human life. } \\
\text { 2. Describe biologically based industrial } \\
\text { products. }\end{array}$ \\
\hline $\begin{array}{l}\text { Describe the scientific method, identify } \\
\text { problems, develop hypotheses, design } \\
\text { experiments, determine variables, } \\
\text { process data, communicate. }\end{array}$ & $\begin{array}{l}\text { 1. Explain the steps of the scientific method. } \\
\text { 2. Planning and carrying out a research } \\
\text { 3. Compile and report research results } \\
\text { 4. Explaining aspects of work safety. } \\
\text { 5. Make a commitment that must be mutually } \\
\text { agreed upon to }\end{array}$ \\
\hline
\end{tabular}

\section{Research instrument}

The research instrument is something that is used to obtain accurate data in a study, this is in accordance with the opinion of Arikunto (2005:134) which states that "research instruments are tools for researchers in collecting data". The quality of the instrument will determine the quality of the data collected, so it is appropriate if the relationship between the instrument and this data 
is disclosed because compiling instruments for research activities is an important step that must be thoroughly understood by researchers. The instrument used is a performance test technique in the form of an assignment, which assigns students to change the interview text into a narrative essay. To determine the ability to write narrative essays, it is determined based on the indicators to be assessed.

\section{Data collection technique Questionnaire}

In the research that the author will do, the type of questionnaire used is web-based. This is due to the pandemic period which is not recommended to meet face to face so that the distribution of questionnaires is only used through the google form application where the access link will be distributed to respondents. Questionnaires will be distributed to three sources with the same subject matter but with different perspectives according to the position of each source.

The author will ask about the use of internet access, the applications used, and the role of technology whether it affects online biology learning. Next, the writer will ask respondents about the mechanism of the online biology learning process, as well as the advantages and obstacles that occur when online biology learning is carried out at MAS Al Wasliyah Marbau Class X MIPA and their responses about suggestions, criticisms, and improvements to the biology learning process. online at MAS Al Wasliyah Marbau Class X MIPA. In making this research questionnaire, the author uses the Google Forms application. This application can be used as an online questionnaire making service so that respondents can fill out the questionnaire given online by clicking on a link that has been provided. The process of making an online questionnaire with the Google Forms application is as follows:

1. The author accesses the website https://:forms.google.com. Then came the HalaMAS Al Wasliyah Marbau.

2. The author fills in the blanks provided according to the desired command. For example, such as the title of the questionnaire, the name of the respondent, position, and class of study if the respondent is a student at MAS Al Wasliyah Marbau Class X MIPA

3. After all the required aspects are listed in the questionnaire, the writer clicks the Send button.

4. After clicking copy, the link will be automatically copied and the author will share the link with the intended respondents. After all respondents filled out the questionnaire, the author was able to see the results of the questionnaire from the author's previously connected Google Drive application. For example in the image below which shows the results of responses from respondents who are directly connected.

Observations made by someone about something that is planned or unplanned, either in passing or over a long period of time, can give birth to a problem (source of the problem). The observations made by the author are based on the biology learning process carried out by each source. At the time of observation, the author will examine the basics of learning used in online biology learning.

For example, regarding the learning implementation plan (RPP) used during online learning. In the online learning observation, the researcher observed the teacher's skills in opening online lessons, presenting materials, learning methods used, language use, time efficiency, and skills in closing learning. The author will also observe how MAS behavior is carried out by students during online biology learning or when learning is finished. The steps in conducting observations made by the author in taking research data are as follows:

1. Determine the theme of the observation

Before making observations, the first thing to do is determine the theme. In this study, the author uses the theme of online biology learning during the covid-19 pandemic. 
2. Determine Observation Objectives

The purpose of this observation is to see how MAS Al Wasliyah Marbau biology learning activities carried out by teachers during the pandemic and whether the learning that takes place is classified as effective.

3. Arrange and Limit Aspects Required.

In making observations, the writer must know the limitations needed to make observations in accordance with the observation sheet that has been validated.

4. Writing Observation Report

After making observations, the writer includes the results he found in the report on the results of the observations

5. Making Conclusions on Observation Results

After the data obtained from the observations, the authors make conclusions from the observations found.

\section{Interview}

Interviews conducted by the authors have a specific purpose, namely to obtain data from the questions posed to each source. With the interview, there is an interaction between the author and the source in obtaining data. The speakers in the interview that will be conducted are the Deputy Head of the Madrasah for Curriculum, biology teachers at MAS Al Wasliyah Marbau, and several student representatives from each grade level. The material that will be presented in conducting interviews with Curriculum WKM is about learning management models, learning systems, learning sustainability plans, guidance and advice to teachers, facilities and infrastructure, as well as parenting programs to support parents/guardians in assisting students in learning. Not only that, the researcher will also ask about the formation of an emergency alert team for handling covid-19 at MAS Al Wasliyah Marbau Class X MIPA education unit, as well as about regular reports to the education office or the ministry of religion. To the biology teacher concerned, the researcher will ask questions about how learning interactions are used in distance learning in the form of online (indoor) or offline (outdoor), training as an increase in teacher skills, especially in the field of biology studies, the role of technology in learning, learning resources, access internet, learning applications, biology learning media used, design of biology learning implementation, and competencies or learning objectives. Furthermore, researchers will also ask about the delivery of learning materials, providing learning motivation, assessment of biology learning, how important the role of parents, discussions between students and teachers, learning constraints, participation and learning rules, virtual face-to-face and the active role of students during the biology learning process. . Likewise, interviews conducted with students used the same material as the teacher as proof of the teacher's arguments regarding biology learning that was carried out during the implementation of learning from home.

\section{Documentation}

In this study, documents in the form of research data originating from sources were collected and attached in the form of documentation. Documentation generated from research can be in the form of images, videos, writings, notes, or verbally.

\section{Data analysis technique}

In this study the author will use the method of data collection with analytical techniques in the search for research data. The data collection for research conducted on online biology learning during the COVID-19 pandemic at MAS Al Wasliyah Marbau Class X MIPA was carried out systematically using interview, observation, questionnaires, and research documentation techniques. After collecting research data, the author will put the results found into a scientific report so that it can be understood by others. In this study the authors use the data analysis method Miles and Huber MAS Al Wasliyah Marbau model. According to Miles 
and Huber MAS Al Wasliyah Marbau, there are three series of activities carried out in data analysis consisting of, as follows:

1. Data reduction (data reduction)

In this section, the data obtained by the author about online biology learning during the covid-19 pandemic at MAS Al Wasliyah Marbau Class X MIPAMAS Al Wasliyah Marbau Class X MIPA will be processed by summarizing, selecting the main points, determining the theme and discarding things. unnecessary in research.

2. Data display

After the researcher conducted data reduction, the next step was the presentation of the data. In this study, the authors present data in the form of an organized description of the biology learning process during the COVID-19 pandemic. So that readers can easily understand the intent and results of the research.

3. Conclusion Drawing/Verification

Next is drawing conclusions or verification. The point is that with the data obtained and processed in such a way, the author can draw conclusions about what was found in research on the effectiveness of online biology learning during the covid-19 pandemic at MAS Al Wasliyah Marbau Class X MIPAMAS Al Wasliyah Marbau Class X MIPA.

4. Data Validity Test

In this study, the validity of the data was tested so that the data obtained by researchers could be scientifically proven and accounted for. The technique of testing the validity of the data used in this study uses triangulation. Triangulation in this study is defined as checking data from various sources, methods, and times with the following explanation:

5. Source Triangulation

Source triangulation to test the credibility of the data is done by checking the data that has been obtained through several sources. In this study, the authors used various sources to obtain data on biology learning during the pandemic at MAS Al Wasliyah Marbau Class X MIPA. The sources used in this study were the Deputy Head of Madrasah for Curriculum, Biology Learning Teachers, and 55 students of MAS Al Wasliyah Marbau, class XI 60 people, and class XII 40 people. From these sources, conclusions are agreed upon based on these sources.

6. Triangulation Technique

Triangulation techniques to test the credibility of research data on the effectiveness of online biology learning during the covid-19 pandemic at MAS Al Wasliyah Marbau Class X MIPA MAS Al Wasliyah Marbau Class X MIPA this is done by checking data from the same source with different techniques. For example, data obtained by interviewing, then checked by observation, documentation, or questionnaires. If the three data credibility testing techniques produce different data, the researcher conducts further discussions with the relevant data source or others, to ensure that the MAS Al Wasliyah Marbau data is considered correct. Or maybe all of them are right, because the point of view is different.

7. Time Triangulation

In researching the effectiveness of online biology learning during the covid-19 pandemic at MAS Al Wasliyah Marbau Class X MIPA MAS Al Wasliyah Marbau Class X MIPA, time also often affects the credibility of the data. Data collected by interview technique in the morning when the interviewee is still fresh, there are not many problems, will provide more valid data so that it is more credible. For this reason, in the context of testing the credibility of the data, it can be done by checking interviews, observations or other techniques in different times or situations. If the test results produce different data, then it is done repeatedly so that the certainty of the data is found. 


\section{RESULTS AND DISCUSSION}

Based on the results above, it can be seen that learning management has been carried out well during the covid-19 pandemic. Good management in learning is proven by the implementation of online learning involving the internet network. also prepared 12 study rooms for teachers who carry out online learning accompanied by a learning picket schedule according to the field of study. Furthermore, in terms of the learning system, it also implements an application-based learning system that can be reached by all students and has previously been socialized through the homeroom. The MAS Al Wasliyah Marbau learning system is carried out based on the online learning roster provided by the school so that teachers are obliged to provide lessons according to the roster. Management is carried out in the form of planning processes, organizing leadership and controlling school activities so that learning objectives can be achieved. In the learning continuity plan section, MAS Al Wasliyah Marbau has prepared several future plans if the pandemic lasts for a long time in the future.

The plan that was prepared was for example learning with a wave system at MAS Al Wasliyah Marbau Class X MIPA students still attended school but not every day, only a few days a week and for a shorter period of time. However, because the Ministry of Religion government regulation regarding wave system learning has not yet been ratified, MAS Al Wasliyah Marbau continues to enforce online learning by monitoring teachers and students on a regular basis. The learning guidance carried out by MAS Al Wasliyah Marbau by implementing integrated attendance for teachers and also conducting training on distance learning.

Every week teachers are also asked to collect lesson plans that have been taught to students to know teachers and students in carrying out learning. Remote learning also requires adequate facilities and infrastructure so that learning can run smoothly Schools prepare study rooms for teachers according to with MGMP in the field of study. This is because teachers are free to come to school but still have to comply with the COVID-19 health protocol. The school also provides headsets that are temporarily loaned to teachers from the computer laboratory to make it easier for teachers to communicate with students.

In the implementation of school learning, they also continue to communicate with parents through the homeroom teacher in terms of collaborating with each other to facilitate the implementation of online learning. It is not uncommon for homeroom teachers to receive criticism from parents about school fees that are not reduced even though learning is not carried out in schools, this is actually being discussed with the principal but has not yet received a decision on how to solve MAS Al Wasliyah Marbau. In this online learning, MAS Al Wasliyah Marbau also formed a covid-19 alert team consisting of teachers in groups as a covid-19 alert team. MAS Al Wasliyah Marbau also has sink facilities to clean hands, digital thermometers to check body temperature, and mandatory masks for anyone visiting the MAS Al Wasliyah Marbau area. also continue to communicate with the Education Office and the Ministry of Religion in terms of reporting on how far MAS Al Wasliyah Marbau learning from home has been carried out and what obstacles have been found, then how does MAS Al Wasliyah Marbau solve the problem. Constraints found in the form of the learning process have not been implemented optimally this is due to the limited scope of teacher and student communication. In addition, signals and networks are also very influential in the implementation of online learning. However, this obstacle can be overcome properly and does not hinder learning so that learning can be carried out properly as MAS Al Wasliyah Marbau usually. 
The implementation of online biology learning at MAS Al Wasliyah Marbau Class X MIPA has been carried out well, for example in terms of lesson plans. The online lesson plan for biology learning has been made by the MAS teacher Al Wasliyah Marbau. The lesson plan is in a simple form which runs out for one meeting. In addition, the learning process is also going well so that learning objectives can be achieved but not optimal because the learning model provided by the teacher tends to be monotonous and only discussions so that there is a lack of variation in learning. At the time of observation, I saw that motivation was given to students in the form of advice on the importance of health and time discipline. Teachers also motivate students online by providing entertainment while studying and reminding students to take care of their health. The assessment given by the biology teacher does not only prioritize numerical values but is based on students' affective and psychomotor. The teacher judges based on the attendance and discipline of students in collecting assignments.

The teacher also gives more value to students who are active in asking and answering the teacher's questions during the learning process. The teacher-student interaction method is carried out online, which MAS Al Wasliyah Marbaua is very dependent on technology or networks. This is also one of the obstacles experienced. Constraints in the lesson, for example, the presence of too few students during online meetings so that learning is less effective in addition to the limited space and time create limitations in teaching. So that the impact on students who get learning is not all, but these obstacles are always sought so that they can be overcome properly. The biology learning media used by the MAS Al Wasliyah Marbau teacher is basically powerpoint. However, it is also equipped with student textbooks and sometimes teachers provide learning videos according to the biology material being taught. Teachers of MAS Al Wasliyah Marbau were also given training in order to improve the quality of teachers, especially in terms of online learning. The training carried out such as training using Google Meet, Google Class Room, and E-Learning.

The MAS Al Wasliyah Marbau teacher uses the group whatsapp application to connect with all students. To some extent, the media can replace the teacher's function as a source of information or knowledge for students. Learning media as a learning resource is a component of the learning system which includes messages, people, materials, tools, techniques, and the environment, which can affect student learning outcomes. Therefore, it can be seen that the level of effectiveness of the implementation of learning from home on biology subjects carried out at MAS Al Wasliyah Marbau Class X MIPA as much as $82 \%$ is running effectively in accordance with government regulations through Circular Letter No. 15 of 2020. About steps What must be done by heads of education units and teachers in carrying out learning from home during the covid-19 pandemic.

\section{CONCLUSION}

1. The inhibiting factors for learning from home in biology subjects are unstable network conditions, the presence of students who are not present in the implementation of online biology learning, the economic condition of students, and not all students have gadgets or laptops so that students cannot join in the implementation of learning biology at MAS Al Wasliyah Marbau Class X MIPA. The supporting factors are the technology that is used by MAS Al Wasliyah Marbau by using the internet network, facilitated learning places, adequate learning resources and learning media, lesson plans designed by teachers, enthusiastic attitude and sense of responsibility of students in studying, and infrastructure. adequate for online learning at MAS Al Wasliyah Marbau Class X MIPA. 
2. Based on research that has been conducted at Madrasah Aliyah Negeri regarding the effectiveness of biology learning during the covid-19 pandemic, it was concluded that as many as $82 \%$ of online biology learning runs effectively in accordance with government regulations through Circular Letter No. 15 of 2020. About steps steps that must be taken by heads of education units and teachers in carrying out learning from home during the covid-19 pandemic.

\section{REFERENCES}

Ananda, Rusydi. 2019. Perencanaan Pembelajaran. Medan: LPPI

Anggraini, Silvia. 2018. Pengaruh Keterampilan Mengajar Guru dalam Membuka dan Menutup Pelajaran Terhadap Minat Belajar Siswa SMK Negeri 1 Beringin. Medan: UIN Sumatera Utara

Aslami, Nuri. 2020. Potensi E-Learning Melalui Sistem Kuliah Online dalam MeningkatkanMutu Pembelajaran Prodi MAS Al Wasliyah Marbau Kelas X MIPAajemen. Skripsi. Medan: UIN Sumatera Utara

Barlian, Eri. 2016. Metodologi Penelitian Kualitatif dan Kuantitatif. Padang: Sukabina

Cahyadi, Ani. 2019. Pengembangan Media dan Sumber Belajar. Banjarmasin: Laksita Indonesia

Jaya, Farida 2019. Perencanaan Pembelajaran, Medan: UINSU

Fathiyah Isbaniah dkk. 2020. PedoMAS Al Wasliyah Marbau Pencegahan dan Pengendalian Corona Virus Disease (Covid-19). Jakarta: Kementerian Kesehatan RI 